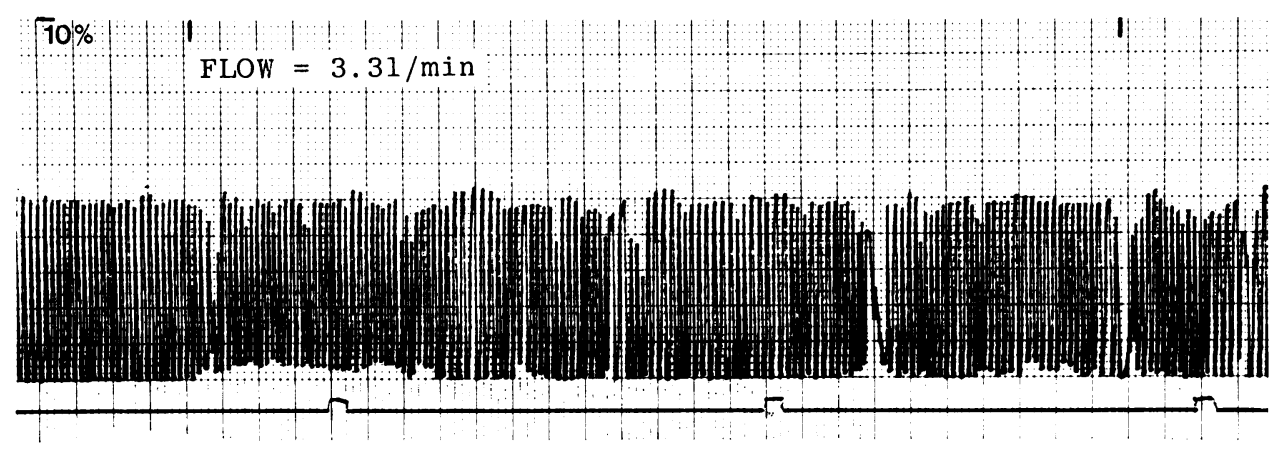

Fig. $2 \mathrm{CO}_{2}$ concentration in expired gases of a $2.5 \mathrm{~kg}$ newborn infant; flow rate $3.3 \mathrm{l} / \mathrm{min}$.

group comprised mixed referrals to his unit; our patients were term mature infants.

J. M. Evans, O. P. Gray, Barbara Holland, and C. A. J. WARDrop Departments of Anaesthetics, Child Health, and Haematology, Welsh National School of Medicine, University Hospital of Wales, Heath Park, Cardiff CF4 4XN

References

Onchi, Y., Hayashi, T., and Ueyama, H. (1957). Studies on the Ayre T-piece technique. Far East Journal of Anaesthesia, 1, 30-35.

Willis, B. A., Pender, J. W., and Mapleson, W. W. (1975). Rebreathing in a T-piece: volunteer and theoretical studies of the Jackson-Rees modification of Ayre's T-piece during spontaneous respiration. British Journal of Anaesthesia, 47, 1239-1246.

\section{Nonhormonal case of adrenal cortical carcinoma}

Sir,

Further to the two articles by Marsden et al. and Visconti et al. regarding adrenal carcinoma in infants (Archives, 1978, 53, 341 and 342) may we add the following account of a child with this extremely rare condition.

A 17-month-old white girl was admitted with a 20day history of malaise, pallor, and high fever $\left(39^{\circ} \mathrm{C}\right)$. She was born after a normal pregnancy and delivery, to a 25 -year-old gravida 2, para 2 woman. Physical examination on admission showed anaemia; both liver and spleen were $2 \mathrm{~cm}$ below the costal margins. No signs of precocious puberty were present, and the clitoris was not enlarged. Blood pressure was normal.

Hb was $7.8 \mathrm{~g} / \mathrm{dl}$, red blood cells being hypochromic; ESR $90 \mathrm{~mm}$ in the 1st hour; serum iron $28 \mu \mathrm{g} / 100 \mathrm{ml}$ (5 $\mu \mathrm{mol} / \mathrm{l})$, TIBC $275 \mu \mathrm{g} / 100 \mathrm{ml}(49 \mu \mathrm{mol} / \mathrm{l})$. Urine analysis normal. Blood and urine culture negative. Urinary VMA $6 \cdot 2 \mathrm{mg} / 24 \mathrm{~h}$ (normal 0 6-7). Bone marrow aspirate showed good cellularity with active myelopoiesis. Blood chemistry-including total protein, bilirubin, sugar, urea, cholesterol, electrolytes, and uric acid was normal. Chest $x$-ray normal.

Four days after admission the patient developed redness and oedema of both eyelids, and on the left frontal region. At that time we also found a palpable lobular mass $6 \mathrm{~cm}$ below the right costal margin. Skull $x$-ray revealed a well defined osteoporotic lesion corresponding with the mass in the left frontal region. A second $x$-ray of the skull 3 days later showed at the same site a picture of osteolysis, and an osteolytic lesion of the left humerus was also present. Intravenous pyelogram showed the right kidney to be displaced downwards. Urinary 17-hydroxysteroids were $0.9 \mathrm{mg} / 24 \mathrm{~h}(3.1 \mu \mathrm{mol} / 24 \mathrm{~h}$ ) (normal for age 1-3.5 $\mathrm{mg} / 24 \mathrm{~h} ; 3 \cdot 5-12 \cdot 1 \mu \mathrm{mol} / 24 \mathrm{~h}$ ), and 17-ketosteroids were zero. Plasma cortisol was $5 \mu \mathrm{g} / 100 \mathrm{ml}(138 \mathrm{nmol} / \mathrm{l})$ in the morning and $4.5 \mu \mathrm{g} / 100 \mathrm{ml}(124 \mathrm{nmol} / \mathrm{l})$ in the evening.

Complete excision of the tumour of the right adrenal was achieved surgically. It was covered by a thin capsule, and measured $12 \times 8 \mathrm{~cm}$. The cut surface was reddishbrown and showed areas of recent and old haemorrhage and evidence of necrosis. Histologically, there were cells with pleomorphic nucleus and a variable amount of cytoplasm, which confirmed adrenal cortical carcinoma. Postoperative chemotherapy with adriamycin was unsuccessful and the patient died 2 months later. Urinary 17-hydroxysteroids, 17-ketosteroids, and plasma cortisol, measured 10 days after surgery, were within normal levels.

\section{A. Constantopoulos, J. Karpouzas, A. XYPolita, and N. MATSANIOTIS 1st Paediatric Clinic of Athens University, Aghia Sophia Children's Hospital, Athens (608), Greece}

\section{Effect of storage and heat on antimicrobial proteins in human milk}

Sir,

The paper by Evans et al. (Archives, 1978, 53, 239) confirms other work on the temperature sensitivity of human milk proteins (Ford et al., 1977; Gibbs et al., 1977). Some of their conclusions deserve comment. 